\title{
Risks of Related Parties in Transition Economy-An Audit Approach
}

\section{Elena Dobre}

Finance Accounting Department, Faculty of Economics, Ovidius University of Constanta, Constanta, Romania

Email: edobreuniv@gmail.co

How to cite this paper: Dobre, E. (2017) Risks of Related Parties in Transition Economy-An Audit Approach. Open Journal of Accounting, 6, 95-101.

https://doi.org/10.4236/ojacct.2017.63008

Received: May 23, 2017

Accepted: July 14, 2017

Published: July 17, 2017

Copyright $\odot 2017$ by author and Scientific Research Publishing Inc. This work is licensed under the Creative Commons Attribution International License (CC BY 4.0).

http://creativecommons.org/licenses/by/4.0/

\section{(c) (i) Open Access}

\begin{abstract}
This paper aims at improving audit practices, at least, for our national audit practitioners. Such possibilities are discussed as case study regarding an audit of a public entity as a related party (relationship \& transactions) with a private company. This reveals a fraud risk by periodical re-negotiating of significant contracts combined with internal controls deficiency. In order to avoid and remove such bad practices, the Romanian financial auditors, fraud examiners, taxation consultants and even legal advisers, need rigorous learning and professional development and adequate evaluation frameworks, combining in a competent responsible manner quantitative and qualitative evaluation made by a peer-review schema. Exclusive quantitative approaches are not adequate for a correct evaluation. An efficient evaluation must involve human specialists, including financial auditor's colleagues. The results for entire professional body may result in higher quality judgments and a good assimilation; not only good practice international standards, but even entire experience of practitioners in this field was recommended. Emphasizing of professional skepticism arises with enough experience.
\end{abstract}

\section{Keywords}

Related Party Transactions, Internal Control Deficiency, Professional Skepticism

\section{Introduction}

We shall begin with a general encouragement about Romania: IMF officials made a brief characterization ${ }^{1}$ : Romania is both undeniably unique, yet also profoundly European. As part of the European family, as part of the global community, Romania can go from strength to strength. Hence, after twenty five years of intense economic reforms in Romania and after last financial downturn,

${ }^{1}$ http://www.imf.org/external/np/speeches/2013/071613.htm 
we still find ourselves in a world of a relative uncertainty. In accounting and audit field, we are still looking for the form and the way of international accounting convergence impact on the systems of Romanian corporate governance (Elena Dobre, 2012) [1]. Our chartered accountants and financial auditors are focused on measures to alleviate the effects of crisis and to ensure an efficient audit approach. Speaking about crisis and solving solutions, IFAC proposes auditing of public sector at global level and European official professional voices consider that "public entities auditing represent a redoubtable weapon in crisis combating" (Michel de Wolf, 2012) [2]. Cause of this new building strategy is linked by the numerous situations when auditor's attention is played on formal audit procedures and much less on identifying financial reporting risks or risky transactions like related parties transactions. In this sense, we find an adequate research methodology from the past experience and case study research. The case study research is too important in the field of public finance and public management studies to be left to the hazard approaches (Dan Remenyi, 2012) [3]. Case study support is the author's own accounting work (no. 473/2012 professional local body number registration) which can represent both legal evidence and specialized scientific research about objective truth (Elena Dobre, 2003) [4]. The final results of this paper based on an authentic case study would be useful to auditors, professional national body and even private and public managers. Also, we believe that our paper would be useful in both finance and accounting study programs of higher education.

\section{Relationship \& Transactions-Case Study on Public Entity Related with a Private Company}

This case study represents in fact a forensic accounting personal work of first author. This case study reflects the image of delegated management in a public entity charged with central heating public service, turned in private company and delegated management became a kind of partnership. A key document was the contract of management in central heating supply which provides in fact, adjusting the price or tariff to cost of Gcal (gigacalory), that adjustment resources to requirements and demands not correlation the requirements and demands with resources according specific regulation ${ }^{2}$. Also, public utilities services are defined by aggregate utility and general public interest ${ }^{3}$, carried to the villages, towns, cities or counties under the direction, coordination and responsibility of local governments, in order to meet requirements of local communities. In our case study, implementation and enforcement of management delegation contract ought to consider the specific provisions of the specific regulations ${ }^{4}$ which establishes the legal framework for the establishment, organization, management, regulation, financing, monitoring and controlling the functioning of public services supply thermal/heating energy produced centrally, to the com-

${ }^{2}$ Government Ordinance no.73/2000 regarding local public utilities, art. 2 lit. k.

${ }^{3}$ Romanian Act of local public services no. 51/2006.

${ }^{4}$ Romanian Act of local public service for heating energy supplying no. 325/2006 
munes, towns and municipalities. These kind of services are established, organized and operated under several principles, including: local autonomy; decentralization of public services; responsibility towards users; ensure the quality and continuity of services; efficient management of public property or private administrative-territorial units, related; promoting public-private partnership; correlation requirements on resources; environmental protection and sustainable development; ensuring public health and quality of life.

All these principles are focusing on permanently growth of standards regarding health and quality of life population in local communities. The right of health protection represents one of the primary tasks of modern state.

\subsection{The Risks Context of the Relationship \& Transactions}

The risks context of the relationship \& transactions between the two entities is done by the public requests: for local heating suppliers is mandatory to setting safety fuel stocks for the winter season. In this case this mandatory condition was not accomplished cause periodical re-negotiating of significant contracts with single fuel supplier which was in the same time affiliate party. There are two simultaneous and linked economic advantages: one is about price of specific fuel named calor and other hand is about receiving dividend from the same source. This is the picture of risky nature of relationship \& transactions. Figure 1 RELATIONSHIP \& TRANSACTIONS SCHEME reveals the relationship \& transactions surprised in February 2012 between:

- Municipality Public Administration;

- SC CT SA-central heating supplier established under public utilities services rules and under a delegated management contract;

- SC RR SA-oil fuel supplier established under Romanian Companies Act ${ }^{6}$;

- SC R SRL_related party 1 with oil fuel supplier;

- C\&C WM-related party 2 with oil fuel supplier.

Questions raised by the legal authorities in this case were about: a) legal objects activity; b) public services delegated management regime; d) kind and nature of relationship existing between involved parties.

Forensic accounting work ordered revealed the risks of defection management and certain indications of fraud. Periodical re-negotiating of significant contracts with related parties and internal controls deficiency designed risk profile. Minimal auditing procedures like general inherent risk identification and materiality threshold would be minimal weapons to prevent rising of public funds from a public entity towards a private company.

The moral of the case study is economics considerations over legal considerations prevalence (substance over form) by applying principle of correlating demands with resources, not upside-down. In this case, a vicious circle was created: fuel price increase involved heating agent tariff of Gcal and this growth was transferred on municipality budget and population expenses with heating in

${ }^{5}$ Romanian Constitution art. 33 http://www.cdep.ro/pls/dic/act_show?ida=1

${ }^{6}$ Romanian Companies Act no.31/1990 


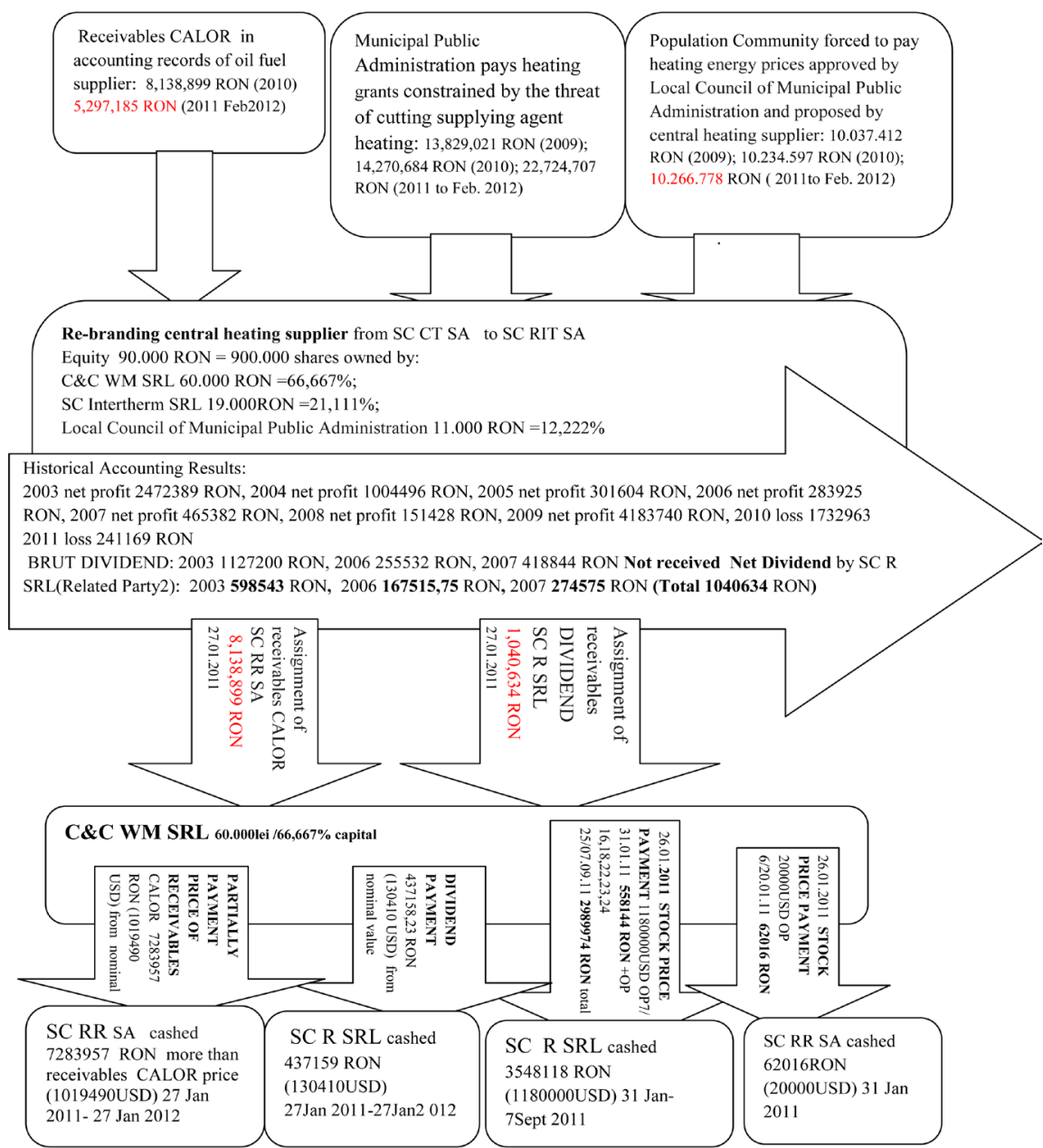

Figure 1. RELATIONSHIP \& TRANSACTIONS SCHEME (February 2012).

winter season. In order to avoid and remove such bad practices, the Romanian local public administration need develop good practices of public acquisition of delegated management contracts. On the other hand, internal auditing and external auditing would do mitigate risks if auditors use not only formal procedures instead holistic approach and professional skepticism.

\subsection{A Handy Minimum Solution to Prevent Risks-Audit Risk Assessment Procedures}

Speaking about need prevention we can reveal after the role of internal audit, the role of external auditors in public entities. For external audit mission is relevant the framework ${ }^{7}$ prescribed by International Standards Audit about risk assessment procedures and related activities. Before this endeavor we need remember that a business means an integrated set of organized and managed activities and assets aimed to obtain profits with lower costs or other benefits for investors, owners or other participants. In fact, public entities are business entities. An entity needed inputs, processes, and outputs to qualify as a business but an entity no longer

${ }^{7}$ ISA 315 Identifying and Assessing the Risks of Material Misstatement through Understanding the Entity and Its Environment paragr. 5-10. 
needs to have outputs or to be self-sustaining to qualify as a busines ${ }^{8}$. The business combinations provide potential risks and in the same time equal opportunities.

Performance of risk assessment procedures aims to provide a basis for the identification and assessment of risks of material misstatement at the financial statement and assertion levels. Hence, risk assessment procedures by themselves do not provide sufficient appropriate audit evidence on which to base the audit opinion the likelihood and impacts of risks are valuable for management analysis and internal controls.

\subsection{Best Practice of Audit Risk Assessment Procedures}

Best practice in this field and practitioners' appreciations ${ }^{9}$ show that the risk assessment procedures should include at least:

(a) Inquiries of management and of others within the entity who in the auditor's judgment may have information that is likely to assist in identifying risks of material misstatement due to fraud or error. However, we may also obtain information, or a different perspective in identifying risks of material misstatement, through inquiries of others within the entity and other employees with different levels of authority.

(b) Analytical procedures: the analytical procedures performed as risk assessment procedures may identify aspects of the entity of which anyone was unaware and may assist in assessing the risk of material misstatement in order to provide a basis for designing and implementing responses to the assessed risks. Analytical procedures performed as risk assessment procedures may include both financial and non-financial information, for example, the relationship between related parties by equity regarding transfer price level according lengtharms principle.

(c) Observation and inspection: the observation and inspection procedures may support inquiries of management and others, and may also provide information about the entity and its environment. Examples of such audit procedures include observation or inspection of the following: (i) the entity's operations, (ii) documents (such as business plans and strategies), records, and internal control manuals, (iii) reports prepared by management (such as quarterly management reports and interim financial statements) and those charged with governance (such as minutes of board of directors' meetings), (iv) the entity's premises and plant facilities.

(d) Observation of changes in the control environment may affect the relevance of information obtained in the prior year. To determine whether such changes have occurred that may affect the relevance of such information the auditor may make inquiries and perform other appropriate audit procedures, such as walk-through of relevant systems.

Any previous experience with the entity and audit procedures performed in previous audits may provide information about such matters as:

${ }^{8}$ Delloite, December 2009, A Roadmap to Accounting for Business Combinations and Related Topics, p. 261.

${ }^{9}$ http://hardi-teh.blogspot.ro/2010/08/risk-assessment-procedures-and-related.html 
(i) Past misstatements and whether they were corrected on a timely basis;

(ii) The nature of the entity and its environment, and the entity's internal control (including deficiencies in internal control);

(iii) Significant changes that the entity or its operations may have undergone since the prior financial period, which may assist the auditor in gaining a sufficient understanding of the entity to identify and assess risks of material misstatement.

Understanding step by step the entity and its environment, including Internal

Control as financial audit good practices ${ }^{10}$, may be presented as below:

- Industry Regulatory framework as well as accounting policies

- Nature of Entity and its Environment

- Objectives and strategies and related business risks

- Measurement and review of Financial performance

- Control Environment: Governance and management ethical and communication/implementation thereof

- Entity risks assessment process: Identifying risks procedures

- The information system, related business processes: Record, Process, Review

- Control Activities: General vs. applications controls; Manual vs. Automated; Performance reviews; Information processing; Physical controls; Segregation of duties; High level authorization non routine items.

- Monitoring of controls

All these procedures may be both useful in risk insolvency and financial crisis of administrative units, recent legal normalized in Romanian economy ${ }^{11}$.

\section{Conclusions}

The case study reveals that internal control weaknesses and poor management gave the chance of fraud like periodical re-negotiating of fuel contract with related parties represent and the revelation of the case study is economic considerations over legal considerations prevalence by applying principle of correlating demands with resources, not upside-down. This case study reveals a fraud risk by periodical re-negotiating of significant contracts and internal controls deficiency. In order to avoid and remove such bad practices, the Romanian financial auditors, fraud examiners, taxation consultants and even legal advisers, need rigorous learning and professional development and adequate evaluation frameworks, combining in a competent responsible manner quantitative and qualitative evaluation made by a peer-review schema. Exclusive quantitative approaches are not adequate for a correct evaluation. An efficient evaluation must involve specialists, including financial auditors. The results for entire professional body could be improved professional judgment quality and a good assimilation. This results not only from good practice international standards, but most importantly from the entire experience of practitioners in this field was recommended. We believe that emphasizing of professional skepticism arises only after expe-

\footnotetext{
${ }^{10}$ https://www.mindomo.com/mindmap/isa-315-33523dda8c1d46fcb4e357ddfd30cfa9

${ }^{11}$ Government Ordinance no. 46/2013 regarding financial crisis and insolvency of administrative units.
} 
riencing enough.

The internal audit profession differs significantly within Europe in terms of profile of internal auditors, characteristics of the internal audit function, staffing, compliance to the IIA Standards and internal audit activities (Maria-Mirela Dobre, 2010) [5]. A handle minimum solution is assimilation and implementation of general risks assessment procedures. This process includes preliminaries actions, internal controls, available and reliable source of information, results and effects on long term. Obvious, assessment of internal controls design remains a critical point in assurance of successful external audit mission risk assessments.

Related parties transactions should be one of the most important objectives of auditing (internal and external). External audit is the last frontier of risks detection and there are great expectations from auditors. They should be "innovative to provide information and opinions about business pattern" (Roger Acton, 2012) [6]. In the context of globalization, national professional communities and also international professional bodies should be more and more united by the same strategy and the same methods to improve the quality of audit. Common events of different professional bodies in accounting, audit and taxation is a good way to contribute of practices improvement. In this direction a FIDEF Conference held in Bucharest in May 2012 had a generous theme: initial and continuous training in accounting, audit and taxation. The main objective of the reunion was the consolidation of cooperation between universities and professional bodies. In this sense, Romanian Chamber of Financial Auditors becomes member of Romanian Association of Economic Faculties ${ }^{12}$. Finally, despite all weaknesses gave by harmonization actions we still believe that Romanian economic reforms already proved a real capacity to implementation of international and European good economic practices, including in accounting and audit field.

\section{References}

[1] Dobre, E. (2012) Approval and Application Accounting Policies-Expression of International Accounting Convergence Impact on the Systems of Romanian Corporate Governance. ECMLG Conference, Cyprus, 8-9 November 2012, 128-136.

[2] Michel de Wolf-FIDEF President-Interview in Audit Practices, Romanian Chamber of Financial Auditors Magazine, No. 1, 2012, pp. 6-8.

[3] Remenyi, D. (2012) Case Study Research-The Quick Guide Series. Academic Publishing International, pp. i-iv.

[4] Dobre, E. (2003) Financial Control Forensic Accounting and Audit. ExPonto, p. 227.

[5] Dobre, M.-M. (2010) Evolution of Internal Auditing in EU Member States. Ovidius University Annals, Economic Sciences Series.

http://stec.univ-ovidius.ro/html/anale/RO/cuprins\%20rezumate/rezumate2010p2.pdf

[6] Roger Acton, ACCA Director-Interview in Audit Practices, Romanian Chamber of Financial Auditors Magazine, No. 2, 2012, pp. 6-8.

\footnotetext{
${ }^{12}$ International Challenges and Trends, Audit Practices, Romanian Chamber of Financial Auditors Magazine, no. 1, 2012, pp. 39-44.
} 
Submit or recommend next manuscript to SCIRP and we will provide best service for you:

Accepting pre-submission inquiries through Email, Facebook, LinkedIn, Twitter, etc. A wide selection of journals (inclusive of 9 subjects, more than 200 journals)

Providing 24-hour high-quality service

User-friendly online submission system

Fair and swift peer-review system

Efficient typesetting and proofreading procedure

Display of the result of downloads and visits, as well as the number of cited articles Maximum dissemination of your research work

Submit your manuscript at: http://papersubmission.scirp.org/

Or contact ojacct@scirp.org 